\title{
A Critical Look at Monetarist Economics
}

\author{
by RONALD L. TEIGEN
}

\begin{abstract}
Ronald L. Teigen is an Associate Professor of Economics at the University of Michigan. He received a PhD degree in Economics from Massachusetts Institute of Technology. Professor Teigen is the author of several articles in monetary economics, and is co-athor with Warren $L$.

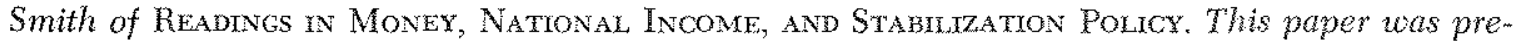
sented at the Annual Conference of College and University Professors of the Federal Reserve Bank of St. Louis on November 12, 1971.
\end{abstract}

$\mathbb{U}$

NTIL JUST a few years ago, the viewpoint which lately has come to be known as "monetarist" was not taken very seriously by anyone except a few dedicated disciples. Its central postulate - that changes in the level of aggregate noney income were due essentially to prior money stock changes - was viewed as a totally inadequate oversimplification, especially since the proponents of this approach failed to provide an adequately detailed explanation of the theoretical structure upon which this tenet was based. ${ }^{1}$ The empirical evidence presented in support of this "quantity theory" viewpoint was subjected to criticism so severe that the evidence has never been taken very seriously."

1/n particular, Milton Friedman's wellmknown article, "The Quantity Theory of Money - A Testatement," in M. Friedman, ed., Studies in the Quantity Theory of Money (Chicago: University of Chicago Press, 1956), pp. 3-21, which has been cited as the basis for much monetarist work, has been shown by Don Patinkin to be a sophisticated version of Keynes" liquidity preference theory rather than the up-to-date statement of an alleged Chicago oral tradition that monetarists take it to be. See Don Patinkin, "The Chicago Tradition, the Quantity Theory, and Friedman, Joumal of Monet, Credit and Banking (February 1969), pp. 46-70.

2I an referring chiefy to the controversy triggered by the work of Milton Friedman and his associates in the late $1950 \mathrm{~s}$ and early $1960 \mathrm{~s}$, especially Friedman's evidence on lags observed between changes in the rate of change of the money stock and changes in GNP, as presented in his paper, "The Supply of Money and Charges in Prices and Output" Joint Economie Committee, U.S. Congress, 1958, and elsewhere, and in the Milton Friedman and David Meiselmans paper on, "The Relative Stabilisy of Monetary Velocity and the Irvestment Multiplier in the United States, $1897-1958$, in Commission on Money and Credit, Stabitization Policies (Englewood Clifs, N.I.: Prentice-Hall, Inc, 1963). The regression results reported in the latter paper were severely criticized by Donald Hester in the November 1964 Review of Economics and Statisticis and by Albert Ando-Franco Modigliani and Michael DePrano-Thomas Mayer in the September 1965 American Economic kavevew. The lead-lag observations discussed in the former paper were criticized by fohm $M$. Culbertson in the December 1960 Joumal of Political Econ omes, and by James Tobin in the May 1970 Quarterly Journal of Economitos.
However, recent years have witnessed something of a turnaround. The conventional wisdom as embodied in modern Keynesian theory has been cast into doubt, while monetarist thinking has increased greatly in popularity, to the point where its proponerts, and even some of its critics, speak of a "monetarist revolution". "The reasons for this rather sudden change are no doubt related in part to the apparent inconsistency of the Keynesian analysis (or at least an elementary version of it) with economic events in the United States during the late $1960 \mathrm{~s}_{3}{ }^{4}$ in some

"See Karl Brumner, "The Monetarist Revolution" in Monetary Theory, Weltwirtschaftiches Archiv (No. 1, 1970), pp. 1-30 and Harry G. Johnson, "The Keynesian Revolution and the Monetarist Counter-Revolution,"American Economic Review, Papers and Proceedings (May 1971), pp. 1-14.

The apparent failure of the income tax surcharge of June 1968 to reduce aggregate demand rapidly has been interpreted by some to be evidence of the failute of the "new" economics. However, it is not at all clear that the surtax was ineffective. In a recenty-publisked strdy by Arthur Okun evidence is provided that, at least in some categories of spending (mondarable goods and services in paticalar), the surcharye seems to have reduced demand substantally, But in other categories (especially demand for new automo" biles) no reduction is apparent. See Arthur $M$. Okun, "rrme Personal Tax Surcharge and Consmer Demand, 1968-70" Brookings Paters on Economic Activity (No. 1 , 1971 ) po. 167-204. More generally, the notion that demand shonld have been observed to fall after the surtax was imposed is based on simplistic and partial analysis. When the surtax is analyzed within the context of a complete model (in which govern. ment sperding is taten into account), and one which incorporates the sophisticated them of consmos havior recently developed - the "permenent income" hypothesis of Milton Friedman or the "life-cyele" hypothesis of Abert Ando and Frano Modiglian - there appena $a$ number of considerations which surgest that no substantid diminetion of total demand could be anticipated. This poinz of view is argued persuasivety by Robett Eisner in his paper, "Fiseal and Monetary Policy Reconsidered" American fonomic Reviets (December 1969) pp. $897-905$. Eisher reasons that rising Goverment expenditure had leen expanding demand rapidly at the time when the surtar was enated furthermore, inder the Friedman and Ando-Modiglian theories, whoh postulate that it is some leng-run measure of income or wealth nather than currentperiod incone which detemines 
degree to monetarist criticism of Keynesian analysis (mostly directed at a very elementary version of it), and in part to other causes, including substantial development by the monetarists of their own theoretical position, as well as the appearance of new and more convincing empirical findings, ${ }^{*}$

While the increase in popularity of monetarism has been rapid, and the rate of growth of the monetarist literature impressive, a cricical hiterature has also appeared, charging that monetarist theory has tumed out largely to consist of old concepts clothed in new names, and that the empirical evidence puportedly supporing the monetarist postion is hiased and un dependable. The purpose of the present paper is to attempt to summarize in a general way the main features of the present monetarist theoretical stance, and to examine the monetarist view of nodern keynesianism. Since much of the debate bears directly on the stabilization policy process and the relative usefuness of different instruments of policy, particular attention will be given to the nature of the transmis. sion mechanism under the two approaches. The empirical evidence will not be discussed in a systematio way in this paper, although reference will be made to it, where appropriate, in the discussion of the theories. In conducting this comprison, I shall attempt to identify issues between the two camps which are real, and those which seen to be false.

\section{The Structure of Monetarist Thought}

Athough the roots of modem monetarist thought extend far back in time the writings of classical economists wre often cited, Irving Fisher being particulaty popular, it is only lately that detaled expositions of this theory have begun to appear. In this paper, no systematic discussion of the entre literature

a household's living standard, a temporary tax change (such as the 1968 surcharge) woth be expected to have only minor efrects on spending because it does not change longrux expected income stanticantly. See Milkon Friedman $A$ rlwory of the Consmption Function (Princenon, N.J. Princeton University Press, 1957 ), and Alpert Ando and Franco

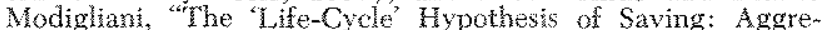
gate Tmplications and "Iest," American Economic Review (March 1963), po. $55-84$.

Harry fohnson, "The Keynestan Revolution and the Monetarst Countr-Revolution, sagges that the succestul nonetarist upstrge may asso be dae to the hactors related to the conversion of the "Keynesian revolution" of the 1930 s into the economic orthodoxy of the $1900 \mathrm{~s}$.

abid. for a general discussion of monetarist theory and its relationship to Keynesian orthodoxy. There have been pulow lished a targe number of papers exital of the recent monetarist empiriol studies; references to some are given in tootnote 2, and a smmary of the cricicm of more recent monetarist empirical work is contained in Ronald 1 . Teigen, "The Keynesin-Monetarist Debate in the U.S.; A Smmmary

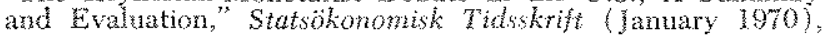
pp. -27 . will be undertaken. Instead, important summary statenents which recently have become available in articles by Andersen, Brumer, Fand, Friedman, and others will be taken to be representative of presentday monetarist thought. ${ }^{3}$

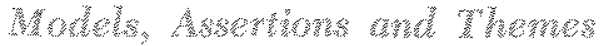

As a useful starting point in establishing a general framework for the discussion to follow, we may refer to recent articles by Bruner and Friedman containing inclusive statements of the monetarist position. ${ }^{8}$ Friedman provides an explicit statement of the staticequllbrium structure which he views as being consistent with both the monetarist and Keynesian schools of thought. The theme he stresses - that it is the particular features of or assumptions about particular characteristics of the general analytic stucture, rather than the fundamental nature of the structure itself, which differentiate monetarists and Keynesians - also appears in the writings of Brunner and others. In summary form, the model set out by Friedman is as follows:

$$
\begin{aligned}
& \text { (1) } \frac{Y}{\mathrm{p}}=\mathrm{C}\left(\frac{\mathrm{Y}}{\mathrm{p}}, \frac{r}{\mathrm{r}}\right)+\mathrm{x}(\mathrm{r}) \\
& \text { (2) } \mathrm{M}_{0}=\mathrm{p}^{\mathrm{L}}\left(\frac{\mathrm{Y}}{\mathrm{p}}, \mathrm{r}\right) \\
& \text { (3) } \mathrm{Y}=\mathrm{py}
\end{aligned}
$$

where $\mathrm{Y}$ is money income, $\mathrm{p}$ is the general price level, $r$ is the rate of interest, $M_{0}$ is the nominal exogenouslyset money stock, $y$ is real income or ontput, and $\mathrm{C}$,

${ }^{7}$ Some of the important articles include Leonall C. Andersen, "A Monetarist View of Demand Management: The United States Experience," this Review (September 1971), pp. 1-11; Leonall C. Andersen and Keith M. Carlson, "A Monetarist Model for Econonic Stabilization," this Review (April 1970), pp. 7-25; Leonall C. Andersen and Jerry L. Jordan, "Monetary and Fiscal Actions: A Test of Their Relative Importance in Economic Stabilization," this Review (November 1968), pp. 11-24; Karl Brunner, "The Role of Money and Monetary Policy," this Review (fuly 1968), pp. 9-24; idem, "The "Monezarist Revolution" in Monetary Theory," idem, "A Sur" vey of Selected Issues in Monetary Theory," Schweizerische Zeitschrift fit Volkswirtschaft und Statistik (No. 1, 1971) pp. 1146; idem, "The Monetarist $V_{\text {tew }}$ of Keynesian Ideas," Lloyds Bank Review (October 1971 ), pp. 35-49; David I. Fand, "Keynesian Monetary Theories, Sabilization Policy and the Recent Inflation," Joumal of Money, Credit, and Banking (Augrst 1969), pp. 556-87; idem, "Monetarism and Fisealisn, Baned Nazionale del Lavoro Quaterly Review (September 1970), pp. 275-89; idem, "A Monetarist Model of the Monetary Process," Joumal of Finance (May 1970), pp. 275-89; Milton Friedman, "A Theoretical Framework for Monetary Analysis," Joumal of Political Economy (March/ April 1970), pp. 193-238; idem, "A Monetarist Theory of National Income," Joumal of Political Economy (March/ April 1971), pp. 323-37.

sFriednan, "A Theoretical Franework" and Brunner, "The "Monetarist Revolution"."

Mr one version of Friedman's statement, the money supply is mate a function of the interest rate rather than being assumed to be exogenoxs. Nowever, this rakes no essential difference to the present discussion, as Friedmati points out. 
I, and L stand for the consumption, investment, and demand-for-money functions, respectively.

Equation (1) is of course the familiar IS curve, from which can be obtained all combinations of real income and the interest rate which will make the flow of planned spending equal to available output, and hence will result in equilibrium in the market for goods and services. Equation (2) is the LM curve, which yields all combinations of real income, the in terest rate, and the price level which will equate the demand for real balances with the real value of the nominal money stock. Equation (3) is a definition relating nominal income and real income or output through the price level. There are of course other markets which could be considered, but which are not explicitly accounted for in equations (1) or (2); in particular, the bond and labor markets are not made explicit. Friedman argues that the assumptions made by the two camps in order to accommodate these markets and simultaneously close the system of equations constitute a fundamental point of difference between monetarists and Keynesians. As written in equations (1)-(3), the model posited by Friedman contains four endogenous variables $-Y, p, r$, and $y-$ and therefore is underdetermined. Monetarism is said by Friedman to include with the above equations a vast number of additional relationships; specifically, a whole Walrasian system of demand equations, supply equations, equilibrium conditions, etc., which in and of themselves determine $y$, the level of real output. The inclusion of a Walrasian system of course implies that the equilibrium position of the model is one of full employment. (There is no such implication for the short-run dynamics of the system, however.) With real output predetermined from the standpoint of equations (1)-(3), equation (1) can be solved for the equilibrium value of the interest rate, and (2) yields the equilibrium price level. Elementary manip. ulation of this system gives the result that only the price level (and the money wage rate, which is not made explicit in equations (1).(3)) will change in response to a money stock change; the equilibrium value of the interest rate is not shifted, and therefore is said to be determined only by "real" variables." In other words, this version of the model displays the well known "classical dichotomy."

According to Friedman, the Keysian approach utilizes a much different and less satisfatctory procedure

\footnotetext{
10This statement is not accurate if the system contains a goverrment sector which issues moneywixed claims against itself, and if real weal th is an argument in the expenditire functions, and/or if the government establishes a tax-expenditure system based on nominal variables.
}

by assuming that the price level, rather than real income, is determined outside of the postulated structure (Friedman refers to ". . . a deus ex machina with no underpinning in economic theory."). ${ }^{11}$ By taking the price level to be exogenous with respect to this structure, the number of variables again is reduced to three ( $\mathrm{Y}, \mathrm{y}$, and $\mathrm{r}$ in this case). However, the system no longer is dichotomized, and all of the variables now are determined jointly rather than recursively. In particular, the static equilibrium levels of both real income and the interest rate can now be changed by both money stock and expenditure changes. ${ }^{12}$

It would be a mistake to conclude from the forego ing discussion that monetarists view themselves as differing from Keynesians only in terms of the assumptions utilized to provide a unique equilibrium solution to the static IS-LM model. There are several other typically monetarist assumptions about the static and dynamic dimensions of this system. Recently, Karl Brunner has introduced four propositions which he asserts are "defining characteristics of the monetarist position." These are: (1) the transmission mechanism for monetary impulses involves a very general kind of portfolio adjustment process ultimately affecting the relationship between the market price of physical assets and their production cost, rather than only the relationship between borrowing costs and the internal rates of return on potential acquisitions of new physical capital, as is asserted to be the mechanism characteristic of modern Keynesian analysis; (2) most of

\footnotetext{
${ }^{11}$ Friedman, "A Theoretical Framework," p. 222.

12 In a more recent article, Fredman has proposed another means of closing this system of equations, which he labels a "third way" to distinguish it from the two procedures outlined in the body of the present paper. He views this ap. proach as intermediate in respect to its theoretical position vis-à-vis the others. However, since it reduces to a relationship between income and the past history of the money stock, as Friedman demonstrates, it seems clearly to fit in with the monetarist point of view. In this approach, it is assumed that the current market rate of interest and the expected market rate are kept equal by the actions of asset holders. The expected market rate, in turn, is set by the expected real ate plus the expected rate of price change (which by definition is the difference between the expected rate of change of nominal income and of real output). By assuming the expected real rate of interest, the expected rate of growth of real output, and the expected rate of growth of nominal income all to be determined outside the system, the market rate of interest is made into a variable determined ontside the system also. Assuming further that the income elasticty of demand for money is unity, Friedman estallishes a direct link between nominal income and the money stock (because under his assumptions, velocity becomes a predetermined variable); this, in tam, enables the "real" sector to be solved. One of the features of this procedure is that it provides an alternative to the assumption of full employment. However, it entails some disadvantages of its own, which are noted in the section of the present paper entitled "Stabilization Policy." See Friednan, "A Monetary Theory of Nominal Income."
} 
the destabilizing shocks experienced by the system arise from decisions of the government with respect to tax, expenditure, and monetary policy, rather than from the instability of private investment or of some other aspect of private-sector behavior, as the Key. nesian view is said to assume. A related belief is that the demand-for-money function is very stable, while the policy-determined supply of money balances is unstable; (3) monetary impulses are the dominant factor in explaining changes in the pace of economic activity, in contrast to the Keynesian position which assertedly takes real impulses as primary; (4) in analyzing the determinants of change in the level of aggregate activity, detailed knowledge of "allocative detail" about the working of financial markets and institutions is of secondary importance and can be disregarded. This implies that the relationship between policy instruments and economic activity can be captured in a very small-scale model-perhaps even in one equation - while the Keynesian position is that knowledge of allocative detail (e.g., substitu tion relationships between various financial assets) is necessary for the proper understanding of policy processes, implying a need for complex structural models. ${ }^{13}$

The statements by Brunner and Friedman are at tempts to sketch the fundamental structure of monetarism. As such, they do not emphasize or even identify explicitly some of the specific characteristic themes which permeate monetarist writing, including their own. Several such themes can be identified.

(1) Great importance is attached to the demandfor-money function, and it is in fact the central behavioral relationship in the monetarist model. ${ }^{14}$ Particular stress is laid on its stability, by which is meant not only that the variance of its error term is small, but much more importantly, that it contains very few arguments. Friedman has written that:

10These "defining characteristics" are discussed at some length in Brunner, "The "Monetarist Revolttion", Section II.

14Thus, for example, David Fand states, "The quantity theory, in its post-Keynesian reformulation, is a theory of the demand for money and a theory of money inoome," "Keynesian Monetary Theories," p. 561. Also, he writes, ". . . the modern quantity theory uses the money demand function to predict the level of money income and prices if output is given, or changes in money income if output varies with changes in [the money stock]," "Monetarism and Fiscalism," p. 228. Friedman has written, "The Quantity theorist not only regards the demand function for money as stable; he also regards it as playing a vital role in determining variables that he regards as of great importance for the analysis of the economy as a whole, such as the level of money income or of prices. It is this that leads him to put greater emphasis on the demand for money than on, let us say, the dernand for pins, even though the latter might be as stable as the former," "The Quantity Theory of Money A Restatement," p. 16.
The quantity theorist accepts the empirical hypothesis that the demand for money is highly stable more stable than functions such as the consumption function that are offered as alternative key relations. .... [T] The stability he expects is in the functional relation between the quantity of money demanded and the variables that determine it ... [and] he must sharply limit, and be prepared to specify explicitly, the variables that it is empirically important to include in the function. For to expand the number of variables regarded as significant is to empty the hy. pothesis of its empirical content; there is indeed little if any difference between asserting that the demand for money is highly unstable and asserting that it is a perfectly stable function of an indefinitely large number of variables. ${ }^{15}$

(2) A particular aspect of the demand for money emphasized by monetarists is that, in their analysis, the stable demand for money is concemed with real, not nominal, balances, while the authorities control the nominal supply, which tends to be quite variable relative to demand. ${ }^{16}$ This state of affairs is usually contrasted with the Keynesian case, in which the demand for money is said to be a demand for nominal balances, either because it is (incorrectly) specified that way, ${ }^{17}$ or because, as in Friedman's discussion summarized above, the price level is fixed so that real and nominal balances are the same. Monetarists use this distinction as part of a rationalization for their contention that their analysis implies a much broader concept of the transmission mechanism for monetary impulses than does the Keynesian model, being based on a very general portfolio adjustment process working through changes in a broad spectrum of asset yields and price level changes, in contrast to the narrow cost of credit channel which is implied by the Keynesian demand-for-money function. This point is developed further in the section entitled "The Transmission Mechanism for Monetary Impulses" below.

(3) Further, monetarists believe the interest elasticity of demand for money balances to be quite low.

15Friedman, "The Quantity Theory of Money - A Restatement," p. 16.

160 n this point Fand writes, "The sharp distinction drawn be tween the supply determined nominal noney stock and the demand determined real stock - a key feature of monetarism-endows the authorities with effective control over the nominal money stock, while severely limiting the extent, and the circumstances, in which they may hope to influence the real value of this stock. If the fornzer assumption extends their control over nominal variables, the latter assumption severely limits their infuence and control on endogenous variables such as the real money stock." See "Monetarism and Fiscalism," pp. 280-81.

17ithis view is taken by David I. Fand in, "Some Issues in Monetary Economics," Banca Nazionale del Lavoro Ouar" terly Review (September 1969), pp. 228-9 and footnote 24, p. 229 . 
Until recently, it was generally thought that they viewed this elasticity to be zero so that the demand for money was linked directly to income as implied by the naive quantity theory. However, such a view has been rejected outright by Friedman and others; ${ }^{18}$ if it ever was held, the accumulation of empirical evidence to the contrary has made it untenable now. ${ }^{19}$

Presently, monetarists take the reputedly different views held by themselves and Keynesians on the size of this elasticity as a basis for contrasting inferences about the expected behavior of velocity in response to a monetary shift. A substantial interest elasticity of demand for money, said to be the Keynesian position, is viewed as implying unstable velocity; Keynesians are viewed by monetarists as not being able to "depend" on the stability of velocity, for as the money stock rises and falls, offsetting velocity changes insulate the rest of the system to a great extent. On the other hand, while not believing velocity to be per. fectly constant, monetarists take the position that ". . . although marginal and average velocity differ, the velocity function is sufficiently stable to provide a relation between changes in money and changes in money income." $=$ In other words, some, but not much, short-run variation in velocity may be expected.". To some monetarists, the essential difference between the two positions is summed up in the demand for money-velocity nexus. Fand writes:

The post-Keynesian quantity and income theories thus differ sharply in their analysis of the money demand function. In the modern quantity theory it serves as a velocity function relating either money and money income or marginal changes in money and money income. . ; in the income theory, it serves as a liquidity preference theory of interest rates, or of changes in interest rates if the price level is given and determined independently of the monetary sector) $=2$

Although it has become fairly common practice to discuss the behavior of velocity in terms of the properties of the demand-for-money function, it is improper to do so because observed velocity depends on all of the behavior - real and monetary - in the macroeco-

\footnotetext{
18Milton Friedman, "Interest Rates and the Demand for Money," Journal of Law and Economics (October 1966), pp. 71-86,

10 Some of this evidence is summarized in David Laidler The Demand for Money: Theories and Evidence (Scranton, Pa.: International Textbook Company, 1969).

20"Fand, "Keynesian Monetary Theories," pp. 563-4.

21 Monetarists do not necessarily expect velocity to change inversely with changes in the money stock. Friedman re cently has written that ". . . the effect on [velocity] is empirically not to absorb the change in $M_{+}$as Keynesian analysis implies, but of ten to reinforce it. ..." "A Theoretical Framework," p. 217.

22 See Fand, "Sone Issues," p. 228.
}

nomic system. This point will be discussed in greater detail below.

(4) The final monetarist theme which I shall mention is concerned with the nature of the response of interest rates to a monetary shift. Monetarists distinguish three components in the observed movement of interest rates: a "liquidity" effect, which is the immediate response before income or other variables have changed, and thus is expected to be in the opposite direction of the monetary shift; an "income" effect, which is the induced reaction of interest rates to the change in income brought about by the monetary impulse, and hence is expected to be in the same direction as the money stock change; and a "price expectations" effect, which comes about because monetary changes cause lenders and borrowers to anticipate a changing price level and lead lenders to protect themselves against the expected depreciation in the value of their funds by charging higher rates. This last effeet would cause market interest rates to change in the same direction as the monetary change. ${ }^{23}$

In looking back over this summary of monetarist thought, it becomes quite apparent that there is a good deal of truth to Friedman's contention that the differences between Keynesians and monetarists are essentially empirical rather than theoretical, having to do with the assumptions made about specific aspects of the commonly-accepted structure, the relative stability and importance in the analysis of different functional relationships, the sizes of various elasticities, etc. ${ }^{24}$ There appears to be little disagreement between the two camps over the specification of Friedman's basic model. ${ }^{25}$ And of Brunner's four

${ }^{23}$ For a discussion of these distinctions, see e.g. William Gibson, "Interest Rates and Monetary Policy," Joumal of Political Eeonomy (May/Iune 1970), pp. 431-55.

207his position is expressed in several of Friedman's writings; for example, see Milton Friedman and David Meiselman, "The Relative Stability" p. 168, and Milton Friedman, "Post-War Trends in Monetary Theory and Policy" $\mathrm{Na}$ tional Banking Review (September 1964), reprinted in M. Friedman, The Optimum Ouantity of Money and other Essays (London: Macmillan and Co., Ltd., 1969), p. 73.

${ }^{25}$ Not all monetarists view this particular model as an appropriate description on which to build an analysis, however. Brunner recently wrote, "It is useful to emphasize... that the logic of the monetarist analysis based on the relative price theory approach requires that attention be directed to the interaction between output market credit market and Walrasian money market. This requirement camot be satisfied by the general framework ased by Friedman. This frameverk is the standard IS-LM analysis offered in an es sentially Keynesian spirit. And this very choice of basic framework actually creates the analytical problems clearly recomized by Friedman in his subsequent discussion. Our analysis established however that the standard IS-LM diagram is not a very useful device for the analysis of monetary processes." Karl Brumner, "A Survey of Selected Issues in Monetary Theory," p. 82 . 
points, at least two are essentially empirical (points numbered (2) and (3) above), while one of the rem maining two (point (1) above) makes a distinction between monetarist and Keynesian views of the transmission mechanism which I believe is false with rem spect to current post Keynesian income-expenditure analysis. Only his last point - that it is appropriate to study the relationship between policy instruments and economic activity without depending on knowledge of "allocative detail" - appears to be one about which there are genuine differences at the theoretical (or perhaps more properly, the methodological) level. Finally, among the four monetarist themes mentioned above, the third one is clearly empirical in nature, and monetarists and Keynesians both in fact hold that this elasticity is nonzero but small in absolute value. In the next section, it is demonstrated that modem Keynesians take the price level to be endogenous, which suggests that the monetarist-Keymesian distinctions summarized above as the second theme are not valid. I shall try to show below that monetarist emphasis on the importance of the demand-for-money relationship (the first theme) is unwarranted, at least in so far as this relationship is viewed as the basis for predicting velocity. I shall also show that the two components of interest rate change in response to a monetary impulse identified in theme four as monetarist are either clearly present in or at least consistent with Keynesian analysis and assumption.

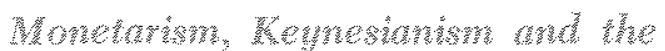 Fras, weren}

As already noted above, monetarists see one of the essential differences between the two sides to be the question of the determinants of the price level in comparative static equilibrium analysis. Keynesians are said to take prices to be fixed so that monetary shifts are reflected in output changes, while quantity theorists believe that monetary changes affect only the price level in this sort of analysis, with real output being determined by a separate subsector of the system.

There is no doubt whatsoever that many practitioners of the Keynesian viewpoint have assumed that prices could conveniently be taken as given for some problems - especially those associated with substan tial unemployment - and that it has often been convenient for simplicity of exposition in undergraduate classroom exercises or for other purposes to make the assumption of rigid prices. It is quite dubious, however, that this assumption, or the liquidity trap assumption which also has been an important element in the monetarist view of Keynesianism, reflects the thinking of most Keynesian economists today. ${ }^{20}$ Rather, the standard static "complete Keynesian system" is widely recognized to be one in which the general price level is one of the variables determined by the interaction of the system, and hence is free to move, but to be one in which there are imperfections in the labor market - most typically, a money wage rate which is inflexible downwards. In other words, rather than assuming that prices are fixed as a means of making the simple static model determinate, modern Keynesians introduce an aggregated labor market and production function into the analysis. ${ }^{27}$ This could be viewed as the Keynesian equivalent of the "Walrasian system of equations" asserted by Friedman to be the hallmark of the adherents to the modem quantity theory approach. It is of course much less satisfactory in that all labor market activity and all kinds of production are aggregated into perhaps as few as two equations (i.e., a reduced-form labor market equation and an aggregate production function) rather than having each market and each activity represented by specific equations. It is more satisfactory on two counts: first, the equations at least are explicitly specified, and second, these equations do not yield the full employment outcome, as is typically the case when depending on a Walrasian system. ${ }^{28}$

26 The liquidity trap is reiected by most economists today be cause little support for it has been found in the many empirical studies of the demand for money which have recently been made. For a summary of some of this evidence, see Ronald L. Teigen, "The Demand for and \$up ply of Money, W. L. Smith and $\mathrm{H}$. L. Teigen, eds., Readings in Money, National Income, and Stabilization Policy, rev. ed. (Homewood, Ill.: Richard D. Irwin, Inc., 1970), Table 2, p. 98, or "The Importance of Money" Bank of England Quarterly Bulletin. (Jume 1970), pp. 159-198.

${ }^{27}$ As evidence for the assertion that modern post-Keymesian static analysis in its most general form typically assumes the price level to be an endogenous variable and that the system of equations usually is made determizate by introducing a supply subsector consistitig of a labor narket and aggregate production function, the following standard works are cited: Gardner Ackley, Mactoeconomic Theory (New York: Macmillan, 1961), Chap. IX, R.G.D. Allen, Macro-Fconomic Theory (London: Macmillan, 1967 ), Chap. 7 , esp. sections 7.6-7.8. Martin I. Bailey, National Income and the Price Level, 2nd. ed. (New York: MeGraw-Hill, 1971), Chap. 3, esp. section 2; Robert S. Holbrook, "The Interest Rate, the Price Level, and Aggregate Output" in W.L. Smith and R.L. Teiqen, edk. Readings in Money, National Income, and Stabilization Policy, rev. ed Franco Modigliani, "The Monetary Mechanism and its Interaction with Real Phenomena," Review of Economics and Statistics (February 1963 Supplement); and Warren 1 . Smith, "A Graphical Exposition of the Complete Keynesian System," Southern Economic Joumal (October 1956), reprinted in W. Smith and $R$. Teigern, eds, Readings in Monet, National Income, and Stabilization Policy, rev. ed. as well as in several other standard collections of readings in macroconomics.

28This discussion is not meant to imply that the simple static Keynesian system contatis an adequate description of the processes which determine the price level. It states simply that the price level is an endogenous variable in the model. 
The essential difference in this regard between Keynesians and monetarists therefore would appear to be that the former view all prices (including wages) as flexible, while the latter consider all prices except the money wage rate to be Hexible (money wages are viewed as inflexible, at least in a downward direction, due to such structural phenomena as minimum wage laws, union contracts, and the like). This distinction has significant implications for the analysis.

In the first place, the Keynesian treatment now cannot be said to be funclamentally less satisfactory than the monetarist one in terms of methodology, except perhaps on grounds having to do with problems of aggregation (Friedman, it will be recalled, used the pejorative term "deus ex machina" to describe what he understood to be the Keynesian approach). Rather, the difference now lies in the analytic usefulness of the assumptions themselves. Is it more appropriate to assume that wages and prices are flexible, or that money wages are sticky while prices can adjust? The answer to this question depends on the nature of the problem being studied in any particular case, and this suggests that an important difference between the two schools of thought may be that Keynesians are more concerned with short-run analysis (for instance, that related to countercyclical stabilization) while monetarist assumptions are more consistent with long-run analysis.

Second, dropping the rigid-price assumption tends to reduce the basis for the heavy emphasis placed by monetarists on the demand-for-money function and its properties. One place where such emphasis is evident is in the discussion of velocity. We turn next to an inquiry into the factors affecting velocity, with particular emphasis on the relationship of velocity to the demand-for-money function.

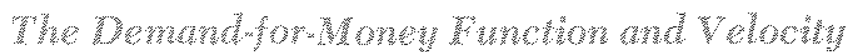

Monetarists, as we have already noted, tend to think of the demand-for-money function as a "stable velocity function" while holding that Keynesians view velocity as unstable, justifying this position by appeal to contrasting assumptions about the price level and the interest elasticity of demand for money (see e.g. the quotes from Fand and others above). The fact of the matter is that the behavior of velocity under the two approaches in response to a monetary shift depends basically on the assumptions made about the labor market, not about the demand for money or about prices, since, as we have seen, both approaches take prices as flexible and, if that is the case, the same general demand-for-money function $\left(\frac{\mathrm{M}}{\mathrm{p}}=\mathrm{L}(\mathrm{y}, \mathrm{r})\right)$ would be characteristic of both. This point can be demonstrated quite easily. First we note that the definition of velocity implies the following relationship:

$$
\text { (4) } \mathrm{E}_{\mathrm{V} \cdot \mathrm{M}_{i 2}}=\mathrm{E}_{\mathrm{y} \cdot \mathrm{M}_{\mathrm{O}}}+\mathrm{E}_{\mathrm{n} \rightarrow \mathrm{M}_{\mathrm{O}}}-1 \text {, }
$$

where $\mathrm{E}$ stands for elasticities calculated on the basis of the interaction of the entire structure, so that (for instance) $\mathrm{E}_{\mathrm{y} \cdot \mathrm{M}_{0}}$ represents the elasticity of real output with respect to changes in the nominal money stock when the response of the entire economic system to the money stock change is taken into account. To distinguish such "systemic" elasticities from "partial" elasticities - those calculated along one function only - the symbol $\eta$ will be used to represent partial elasticities. Thus, for instance, $\eta_{\text {L.r }}$ will stand for the interest elasticity of the demand for real balances, holding income and other variables constant.

Under the monetarist assumption of flexible wages and prices, real output is determined uniquely by Friedman's "Walrasian system" and, as he points out, is to be considered as predetermined from the standpoint of equations (1) - (3). This means that a monetary shift cannot change real output (i.e, the multiplier $\frac{d y}{d M_{0}}=0$ ), so that $E_{* * M_{0}}$, which is defined to be $\frac{\mathrm{M}_{\mathrm{o}}}{\mathrm{y}} \frac{\mathrm{dy}}{\mathrm{dM}_{0}}$, also is zero. By differentiating equations (1) (3) with respect to $M_{0}$ while holding $y$ constant, it

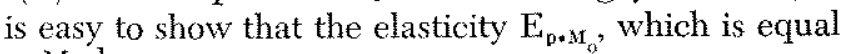
to $\frac{M_{0}}{p} \frac{d p}{d M_{0}}$, has a value of unity. Inserting these results into (4) gives the quantity theory result that $\mathrm{E}_{\mathrm{Y} \cdot \mathrm{M}_{0}}=0$, the "stable velocity" result referred to previously. It is important to note that no particular assumptions unique to the monetarist position were made about the demand for money per se; the assumption which yielded this result was that the demand for labor and the supply of labor both were functions of the real wage rate, and that the market was always cleared.

On the other hand, let us consider the Keynesian case, which we now define as one in which money wages are sticky (i.e., there exists money illusion in the supply of labor), but in which the price level is an endogenous variable. To analyze this case, we must add three equations to the basic model: an aggregate production function (equation (5) below); a labor market summary equation which states that the supply of labor services per unit time (N) is infinitely elastic over a wide range of employment at whatever money wage rate prevails, and that the demand for labor $\left(N^{D}\right)$ is determined by the real wage $(w)$ (equation (6)); and a definition which states that the 
real wage is the ratio of the money wage rate (W) and the price level (equation (7)). The bar over the money wage rate indicates that it is being held constand here. 'This gives:

(5) $y=y(N)$

(6) $\mathrm{N}=\mathrm{ND}(\mathrm{w})$

(7) $\mathrm{w}=\frac{\overline{\mathrm{W}}}{\mathrm{p}}$.

By differentiating the system defined by equations (1) - (3) and (5) - (7) totally with respect to $M_{0}$, expressions for the systemic elasticities $\mathrm{E}_{\mathrm{y} \cdot \mathrm{M}_{0}}$ and $\mathrm{E}_{\mathrm{D} \cdot \mathrm{M}_{0}}$ can be found. They are as follows (see the appendix for their derivation):

(8)

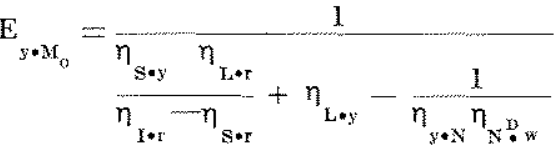

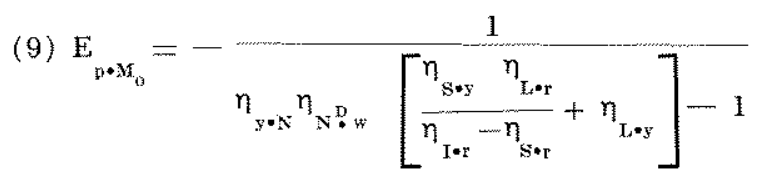

Here $S$ stands for the savings function; otherwise all of the notation has already been defined. The usual slope assumptions are made, and on the basis of these assumptions, both of these systemic elasticities will be positive ${ }^{30}$ Whether velocity will rise, fall, or remain constant in the face of a monetary shift depends on the sizes of all of the partial elasticities and their relationships to one another as given by these expres" sions. The demand-for-money elasticities play a role, but are by no means the only relevant elasticities. In general, we would not expect the elasticity of velocity with respect to nominal money balances to be minus unity in value, as the "liquidity trap" assumption implies. It will approach that value if $\eta_{\mathrm{L} . \mathrm{r}}$ or $\eta_{\mathrm{s.y}}$ are very large, or if the term $\left(\eta_{1 \cdot *}-\eta_{g \cdot r}\right)$ is very close to zero. 31

29This is the simplest method of introducing a Keynesian-type assumption into the analysis; it is by no means the only possible way of doing so. The nature of and reasons for the existence of money illusion in the labor market is the subject of a considerable amomt of literature. See, for example, Axel Leijonhufvud, On Keynesian Economics and the Economics of Ketnes (London: Oxford University Press, 1968 ).

$30 \mathrm{t}$ is assumed that $\mathrm{r}_{\mathrm{g} \cdot \mathrm{r}}$ is either positve or, if negative, that it is smaller in size than the absolute value of $\eta_{I * r}$. A listing of all the slope assumptions is given in the appendix.

3 Since the numerator of the expression for $\eta_{g-y}$ is one minus the MPC, ns.y is not expected to be large. As noted in footnote 26 , belief in a very large interest elasticity of demand for money $\left(\eta_{\text {L.. }}\right)$ is not a characteristic Koynesian stance. Reference to the stmmaries of avaluable empirical evidence mentioned in that footnote will show that this elasticity actually appears to be rather small (almost certainly less than inity in absolute value, and in many studies smaller in absolute value than 0,2 ).
To summarize, the main point of this exercise was to show that, using a common model with no special assumptions about the properties of the demand for money, it has been possible to derive "monetarist" and "Keynesian" results for the response of velocity to a monetary shift. It is improper to speak of the demand for money as a "velocity function", especially in the monetarist case where it is assumed that money wages are flexible so that the system equilibriates at full employment. In that case, the velocity elasticity will be zero no matter what the sizes of the demand-formoney elasticities.

Eliminating the rigid-price assumption as a basic point of difference between the two schools reduces the basis for monetarist emphasis on the demand for money for other" reasons besides its implications for velocity. It also is important for monetarist views on differences in the nature of the transmission mechanism for monetary policy. It is to this subject that we turn next.

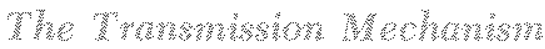

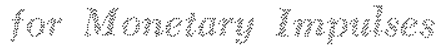

One of the most characteristic themes of monetarism is the heavy emphasis which is placed on differences between the quantities of money demanded and supplied as the prime factor motivating spending and, hence, changes in income and prices. Friedman and others have explained again and again how the authorities can change the nominal money stock, but how it is money holders who determine the velocity with which that stock is used, and ultimately who determine the stock of real balances through the effects of spending decisions on the price level. As Friedman puts it, "The key insight of the quantity" theory approach is that such a discrepancy [between the demand for and supply of money] will be manifested primarily in attempted spending, thence in the rate of change in nominal income." 32 In other words, when households and firms are holding more cash balances than are desired at current levels of income and interest rates, they convert these excess balances into other assets, both financial and physical; the market value of physical assets ultimately changes, making the production of new assets more attractive. The change in the general price level which occurs as a result of this process, and the change in output, both work toward a re-equating of the real value of the nominal money stock and the demand for real balances. Thus the monetarists clearly embrace a very

32Friedman, "A Theoretical Framework," p, 225. 
general kind of portfolio adjustment view of the transmission mechanism in which the relevant portfolio contains financial and physical assets of all kinds. ${ }^{33}$ It will be recalled that this is the first of Brumner's four "defining characteristics." At the same time, monetarists have been taking Keynesian analysis to lask for focusing almost exclusively on interest rates representing the "cost of finance" as the channel through which monetary impulses are felt. The following quotation makes these distinctions very clear:

The Income-Expenditure theory of the Fiscalists adopts a particular transmission mechanism to an alyze the effects of a change in the money stock (or its growth rate) on the real economy. It assumes that money changes will affect output or prices only through its effect on a set of conventional yields on the market interest rate of a small group of financial assets, such as government or corporate bonds. $\mathrm{A}$ given change in the money stock will have a calculable effect on these interest rates ... given by the liquidity preference analysis, and the interest rate changes are then used to derive the change in investment spending, the induced effects on income and consumption, etc.

Monetarists, following the Quantity theory, do not accept this transmission mechanism and this liquidity preference theory of interest rates for several reasons: First, they suggest that an increase in money may directly affect expenditures, prices, and a wide variety of implicit yields on physical assets, and need not be restricted to a small set of conventional yields on financial assets. Second, they view the demand for money as determining the desired quantity of real balances, and not the level of interest rates. Third, and most fundamentally, they reject the notion that the authorities can change the stock of real balances - an endogenous variable - and thereby bring about a permanent change in interest rates. . . .

Monetarists reject the liquidity preference interest rate theory because it applies only as long as we can equate an increase in nominal money with a permanent increase in real balances. This suggests that the hiquidity preference theory may be useful as a theory of the short run interest rate changes - the liquidity effect - associated with the impact effects of nominal money changes. 34

Statements like this, and the quotation from Friedman in footnote 14 indicate that monetarists believe their view of the transmission mechanism to differ from the position they impute to the Keynesian camp most essentially in differences in assumptions about characteristics of the demand-for-money function. The interpretation of the interest rate term in this function plays a role; so does the question of price flexibility.

\footnotetext{
${ }^{33} \mathrm{~A}$ description of the classes of assets involved and the nature of their yields is given in Milton Friedman, "The Quantity Theory of Money - A Restatement."

24Fand, "A Monetarist Model," pp. 280-81.
}

As the preceding discussion and quotation indicate, monetarists think of their own view as an extremely general one. The interest rate term in their model really stands for a vector of yields on many assets, some of them financial yields determined in the money and capital markets, and some of them implicit yields on real assets. A monetary impulse sooner or later affects all of these yields, and hence adjusts the demand for real balances directly as well as indirectly through the effects of yield changes on income. At the same time, changes in the price level which result will adjust the real value of the nominal money supply. Therefore the adjustment process is seen as being summarized in the characteristics of the demand-forreal balances function and its relationship to the nominal money supply. Keynesians are said to include only a few market-determined yields on financial assets in their liquidity-preference function; furthermore, the price level is exogenously determined. Therefore the process of adjustment to a monetary impulse is supposedly seen by them in much narrower terms - the entire process takes place through adjustment of the demand for money, and basically is said to focus on the cost of credit as reflected in market interest rates. Furthermore, the belief in a substantial interest elasticity of demand for money, often attributed to Keynesians, means that a monetary impulse will have a relatively small effect even on these rates.

These distinctions must be regarded as artificial. First, there is nothing inherent in the Keynesian system which is inconsistent with the introduction of a general portfolio adjustment transmission mechanism; and, indeed, there has been a substantial development in this direction in Keynesian thinking and practice during the last several years. On the theoretical side, the work of Tobin and others may be cited, while at the operational level, the developers of the Federal Reserve Board-MIT econometric model of the U. S. economy have attempted to incorporate such a mechanism into their model. ${ }^{35}$ While all of the problems involved in this attempt have not yet been solved, work is continuing and improvements will be made. Second, as we have already shown, Keynesians take the price level to be endogenous, and thus recognize

\footnotetext{
35For a non-monetarist example of the development of portfolio theory, see James Tobin, "An Essay on Principles of Debt Management," in Commission on Money and Credit, Fiscal and Debt Management Policies (Englewood Clifs, N.J.: Prentice-Hall Inc., 1963), pp. 143-218, esp. Part II. Features of the Federal Reserve Board-MIT model are discussed in Frank de Leeuw and Edward M. Gramlich, "The Channels of Monetary Policy," Federal Reserve Bulletin (June 1969), pp. $472-91$
} 
the same process of adjustment of the nominal money supply through price level changes as the monetarists. ${ }^{30}$

There remain certain problems with monetarist thought on two subjects related to the transmission mechanism. One is a misunderstanding, in my opinion, of the relationship between money and interest rates implied by Keynesian theory. The other has to do with the monetarist position on the money stock as a force driving income through the portfolio process mentioned above.

Liquidity preference theory, money, and the rate of interest - Monetarists view themselves as holding a "monetary theory of the price level" under which monetary shifts are reflected (in the longer run, at least) primarily in price level changes. They take the stance that Keynesians hold a "monetary theory of the interest rate," Under this phrase, at least two positions are subsumed. Some monetarists seem to think that Keynesians see the money supply together with the demand-for-money function (specified in nominal terms) as determining the level of interest rates. Others recognize that the interest rate in Keynesian analysis is determined jointly as one of the outcomes of an interacting system of relationships rather than just by one behavioral relationship (i.e., by some version of an IS-LM system like Friedman's summary model). Whichever view is held, however, it is asserted that Keynesian analysis leads to the conclusion that monetary shifts result in interest rate changes in the opposite direction, while monetarist analysis suggests that movements of $\mathrm{M}$ and $\mathrm{r}$ in the same direction will be observed. ${ }^{3 \pi}$

Neither version of the "monetary theory of the interest rate" is an accurate representation of Keynes-

36 Semantic as well as real issues are involved in discussions of this subject. For example, Brumer labels anyone who sulscribes to a portfolio adjustmont view of the monetary transmission Inechanism a "weak monetarist". See Karl Brumer, "The Role of Monetary Policy," this Review (July 1968), pp. 9-24.

sas an example of the frot of these positions, the following quotation from a recent article by Fand is offered: "In the Keynesiat theory the exogenonsly given quantity of money, together with the licuidity preference function, detemines the interest rate" Fand, "Keynesian Monetary Theories," p. 564. The second is illustrated by a quotation from Zwick; "The alternative concepts of Keynes and Fisher concerning the adiustment of the economy to monetary changes are mirrored in their different notions concerning interest rate detemination and the response of interest rates to monetary charges. "The IS-LM framework singests that so long as the IS and LM schedules represent independent relations, a monetary expansion calses interest rates to fall becalase of the outward shift of the IM schedule. In the Fisherian model, a monetary increase rasses the level of expenditures; the upward response of loan demand due to the increased expenditures causes interest rates to rise." Burton Zwick, "The Adiustment of the Economy to Monetary Changes," Journal of Political Economy (January) February 1971 ), p. 78 . lan thought, for both imply that an expansionary monetary impulse (for example) can only result in a lower interest rate in the new equilibrium. In other words, it appears that of the two monetary effects on interest rates often mentioned by monetarists which are relevant for static analysis - the liquidity effect and the income effect-Keynesians are supposed to recognize only the liquidity effect, or more generally, are supposed to be basing their analysis on assumptions which can only result in an inverse relationship between monetary impulses and interest rate changes.

This is certainly not the case. When the entire structure is taken into account, rather than only the liquidity preference function, the level of interest rates in the new equilibrium relative to the initial position is determined by a number of elasticities, nost importantly those which are the determinants of the slope of the IS curve. If its slope is positive - which is the case if all of the propensities to spend with respect to total income sum to more than unity - then both income and interest rates will be higher in the new equilibrim than in the old, ${ }^{38}$ This is such a wellknown case as to require no farther comment.

Of course, equilibrium positions are not observed in the real world; instead, the economy is always in transition, moving toward resting points, which themselves are repeatedly being disturbed. It may be inferred from some monetarist writings that it is the observed tendency of interest rates and money to move in the same direction which is thought to be inconsistent with Keynesianism, rather than the possi* bility that money and interest rates can move together in terms of comparative equilibrium points. In other words, the discussion may refer to the dynamics of the system, rather than the comparative statics. In this area, the monetarists have done us all a service by stressing the possible inportance of price-expectation effects on interest rates, a phenomenon which typically has not been incorporated into dynamic Keynesian models. I will argue that observed parallel move. ments between money and interest rates are quite consistent with the basic IS-LM structure (no matter which way the IS curve slopes), given the reasonable and widely-accepted premise that the monetary sector adjusts much more rapidly than the real sector to ex-

\footnotetext{
38 An upward-sloping is cure cannot be obtained from Friedman's summary model, because only consumption spending is related to income in that model, and the notion that the MPC is less than unity is a fundamental postulate of masroeconomic analysis. However, the level of income might well appear in other expenditure functions, such as the investw ment relationship (where the rationalization would be that investment depends on profits, which in turn are a function of the level of income).
} 
ternal shocks. Under this premise, observed values of income and the rate of interest may be supposed, at least approximately, to be such that the LM equation is always satisfied during the process of adjustment from one equilibriun to another, while the IS equation is not. I will argue further that price-expectation effects are readily accommodated by this analysis.

The implications of these differing speeds of adjustment are illustrated on the accompanying figure, which happens to be drawn with a downward-sloping IS curve. Assume the system to be initially in equilibrium at point $F$, so that the equilibrium values of the interest rate and income levels are $\mathrm{r}$ and $\mathrm{y}$. Now let there occur an expansion of the money supply, so that the LM curve shifts outward to a new position, LM'. According to the assumption made above concerning the relative speeds of adjustment of the monetary and real sectors, this shift will result first in a fall in the interest rate from its initial equilibrium level to a new level, $\mathbf{r}^{\prime}$. It should be noted that this is the "liquidity effect" which is recognized by monetarists as being present both in their own and in Keynesian thinking. It represents a movement along the liquidity preference function in response to a change in the money supply, holding income constant. Next, income will begin to respond, and income and the rate of interest both will rise along the segment $\mathrm{GH}$ of $\mathrm{LM}^{\prime}$ to point $\mathrm{H}$, the final equilibrium position. This movement, of course, reflects the "income effect." If rising income is accompanied by rising prices, there will also be an induced shift of the LM curve during the transition. For example, it might move to a position like $\mathrm{LM}^{\prime \prime}$ as shown. Alternatively, it could move to a position to the right of $\mathrm{LM}^{\prime}$.

Such LM shifts reflect the operation of two forces. First, rising prices reduce the real value of the new nominal money stock and "tighten the money market" after the initial expansionary pulse. This has the effect of moving the LM curve leftward. Second, rising prices may engender expectations of future price increases. If, as has been suggested, the demand for money depends on nominal interest rates while real expenditures are determined by real rates, then the "price expectations effect" mentioned previously would cause a rightward LM shift, resulting in a lesser leftward overall shift in the LM curve than that brought about due only to the drop in the real value of the nominal money stock, or perhaps even a net rightward movement (in this discussion, the vertical axis is interpreted as measuring the real rate of interest). If these effects are present, the adjustment path followed from point $\mathrm{G}$ might be the dotted one instead of the solidly-drawn one, and the system wonld end

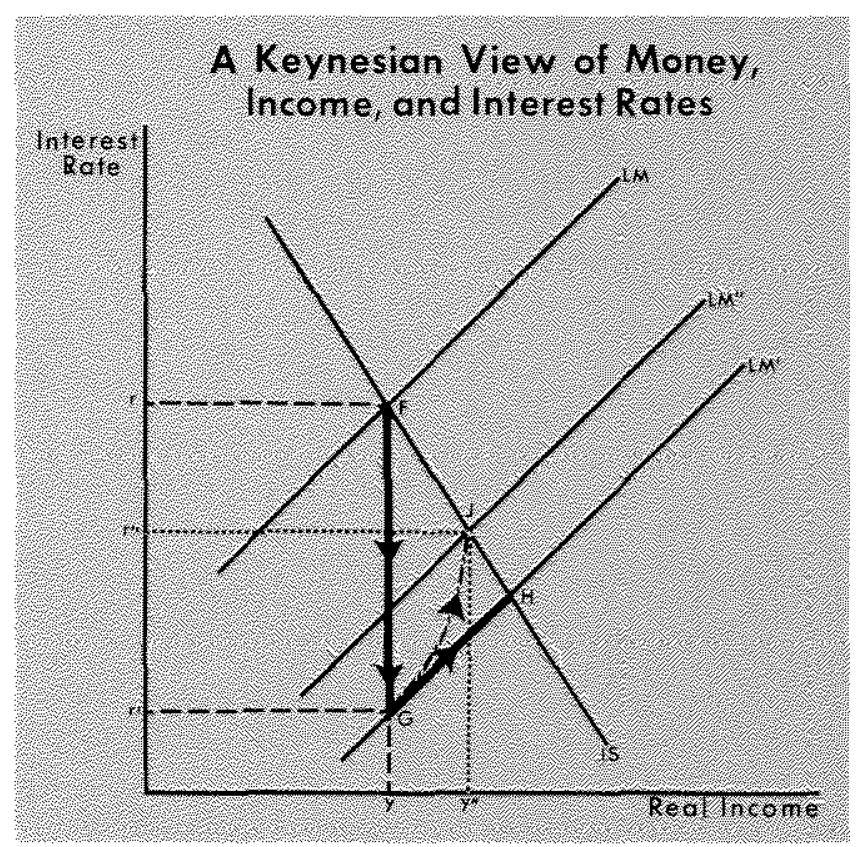

up at a point like $\mathrm{J}$ instead of $\mathrm{H}$, so that the new equilibrium income level would be $\mathrm{y}^{\prime \prime}$, and the equilibrium real interest rate $\mathrm{r}^{\prime \prime}$. Incidentally, if price-expectation effects are present, a value of $r^{\prime \prime}$ for the real rate is quite consistent with a market rate above $r$.

We may conclude from this discussion that there is no reason to be surprised by the fact that during much of the time following an increase in the money supply, interest rates are observed to rise. A standard assumption about relative speeds of adjustment, much used by Keynesians, directly reflects both the "liquidity effect" and the "monetary effect" often discussed by monetarists, and is perfectly consistent with the presence of price expectation effects. Second, it is appropriate to point out that this entire discussion has been carried out in the context of a pure multiplier model. If accelerator effects are present, they may accentuate the pure multiplier effects of a monetary shift on interest rates, at least during parts of the adjustment period. Finally, there is the likelihood that in many cases in which interest rates and the money stock move together, the monetary authorities are reacting to shifts in spending. For instance, if total spending rises, interest rates will go up and the monetary authorities will often try to moderate the interest rate increase by expansionary open market operations, resulting in a rise in the money stock.

The monetarist view of money as a force driving income - It is self-evident that monetarists typically have assigned great importance to changes in the money stock as the prime moving force behind income changes. For instance, one of Brunner's "de- 
fining characteristics of monetarism" is that ". . . the monetarist analysis assigns the monetary forces a dominant position among all the impulses working on the economic process." investigations into the lead-lag relationship between changes in the rate of change of the money stock and changes in income are too well-known to require further comment, ${ }^{43}$ At the same time, monetarist writings often seem to suggest that Keynesians view monetary policy as ineffective.

Keynesians view monetary policy as effective and useful, and to suggest the opposite is to raise false issues. But this does not mean that they necessarily consider changes in the money stock to have particular causal significance. Monetary policy is carried out through the traditional instruments - open market operations, discount rate changes, and variations in reserve requirements - and not by direct manipulation of the money stock. It is true that in simplifed versions of the Keynesian model, monetary policy is represented by the money stock, which is assumed to be controlled by the authorities and which replaces the instruments named above. It is also possible that the authorities could control the nominal money stock to almost any desired degree of precision. But in the real world, or in the more sophisticated models of it, the nominal money stock is not exogenous, nor has it been controlled as an objective of policy by the central bank in the United States; it, or its components, are determined jointly by the central bank, the commercial banks, and the public, and it is basically a passive outcome of the interaction of the economic system, not a driving force,

The doubt that Keynesians feel concerning monetarist assertions about the potency of money stock changes reflects the fact that monetarist descriptions of the adjustrment process themselves seem to give no particular reason for regarding money stock changes as causal. These descriptions typically run as follows, using an open market purchase of Treasury bills as an example: ${ }^{41}$ at the outset, there is an exchange of assets between the central bank and a Government securities dealer, with the central bank giving the dealer its check drawn on itself in exchange for bills.

\footnotetext{
39Brunner "The "Monetarist Revolution"," p. 7.

toilton Friedman, "The Supply of Money and Changes in Prices and Output, ${ }^{3 x}$ in The Relationship of Prices to Economic Stability and Growth, Compendium of Papers Submitted by Panelists Appearing Before the Joint Economic Committee, 85th Congress, 2nd sess., 1958, pp. 241-56.

11 See, for instance, Milton Friedman and David Meselman, "The Relative Stability," Sec. VII, and Milton Friedman and Anna J. Schwartz, "Money and Business Cycles," Review of Economics and Statistics (February 1963 Supplement), esp. pp. 60-6I.
}

This exchange results in the following: (1) a reduction in the yield on bills, with consequent disequilibrium among holders of securities; (2) an increase of bank reserves of an equivalent amount (disregarding drains into currency holdings, etc.); (3) an initial increase in the money supply of the same amount as the transaction; and (4) a decrease in bill holdings by the private sector, with a concomitant increase in the central bank's portfolio. In a process deseribed in some detail by Friedman and Schwartz, the next step will involve action to readjust portfolios in response to yield and wealth changes; meanwhile, banks will be interested in expanding loans on the basis of their newly-acquired reserves (and incidentally in creating new deposits). Eventually the adjustment affects the yield on equities and therefore the market value of the existing stock of physical capital. The existing capital stock will rise in value, stimulating the production of new capital and thus causing income to rise. There may also be other effects, such as direct effects on spending of changes in wealth.

The question would seem to be whether it is the initial increase in the money stock, the full increase (including the new deposits generated as a consequence of loan decisions), the increase in bank reserves, the reduction in private bill holdings, the fall in yields, the increase in the central bank's portfolio, or some other factor which is responsible for the income change. Rather than arbitrarily selecting some one factor from this list, it would seem preferable to take the more general view that the initiating force was the disturbance of a portfolio equilibrium, effected in this case through open market operations. (Such a disturbance, with similar effects, could arise for other reasons: e.g., if there were a change in wealthholders' preferences for holding a particular security category at existing yields.) The change in the money stock is properly viewed as one of the several results (along with changes in income, interest rates, prices, etc.) of this disturbance. Such a position of course implies that monetary policy is effective, but does not assign the starring role in the drama to changes in the money stock.

\section{Stabilization Policy}

Modem Keynesian static analysis, based on the complete Keynesian system with flexible prices and inflexible money wages, yields the result that both monetary and fiscal policy are able to effect changes in income, interest rates, prices, employment, and other variables. Monetarist analysis, however, takes the position that only monetary policy has significant effects on the pace of economic activity, at least in 
the short run. This suggests that the two schools of thought disagree not in their views about monetary policy, but rather on the effectiveness of fiscal policy.

Until recently, monetarists were interpreted as basing their belief that fiscal policy is ineffective directly on the presumed existence of a stable demand-formoney function with zero interest elasticity, together with the assumption of an exogenously-set money stock. Such a demand-formoney function links money and income directly together, so that income cannot change unless the money stock changes. Shifts in govemment spending financed by bond issue, for instance, were said to result in interest rate changes of sufficient magnitude to reduce private spending to the degree required to keep total demand at a constant level.

However, given the many research studies which show otherwise, it has become impossible to maintain that the interest elasticity of the demand for money is zero. This development has had a considerable effect on the tone of monetarist discussions. Thus Fand, in discussing stabilization policy, refers to "... the exceptional case of a completely (interest) inelastic demand for money." Furthermore, a relevant recent finding is that the supply of money is interestelastic, and that this is sufficient to loosen the tight link between the money stock and income even if the interest elasticity of demand is zero.

Therefore monetarists have had to tationalize their dismissal of fiscal policy in other ways. Some have tried to find other means of solidifying the moneyincome link and of segregating the monetary sector from the remainder of the system by neutralizing the comnection provided by the interest rate. One way of doing so is by considering the interest rate to be determined exogenously. This, in effect, is the procedure followed by Friedman in his paper entitled, "A Moretary Theory of National Income" 43 If interest rates do not respond to changes in real and financial variables, the rigid money-income connection is preserved. This may be considered the most extreme approach, because under it fiscal policy does not even affect the rate of interest and the division of output among the various sectors.

Another way is to make the standard quantity. theory assumption of Hexible wages and prices, and hence full employment, while accepting the fact that the demand for and supply of money balances are interest-elastic. In such a world, fiscal policy cannot

4FFand, "Monetarism and Fiscalism," p. 289 (italics added).

43ee the discussion of this approach in footnote 12 . affect the levels of real variables like output or employment, which are entirely detemined by the labor maket and the production technology of the system - but then, neither can monetary policy.

Assumptions are not a matter of logic, assuming that they are internally consistent. In weighing these various approaches to the analysis of stabilization policy, the most important questions probably should be: Which of the altemative approaches is the most realistic and the most relevant for the real-world question of fiscal policy's effectiveness? Is it the case of flexible wages and prices, so that full employment is the rule and not the exception, and neither monetary policy nor fiscal policy can affect the level of real activity? Is it the case involving exogenouslydetermined interest rates, so that fiscal policy cannot even affect the division of output, let alone the level of activity? $\mathrm{Or}$ is it the case of flexible prices but a sticky wage level, in which case monetary and fiscal policy both are capable of affecting the level of real activity?

Brumer has taken a somewhat different approach to the analysis of fiscal policy than have most other monetarists. He asserts that fiscal policy is ineffective or perverse because the effects on asset values due to interest-rate changes of the cumulation or decumulation of clains against the Covernment held by the public, resulting from a fiscal policy deficit or surplus, oukweigh the direct effects on the flow of output and income of new spending and taxing and of the changes in the stock of financial claims held by the private sector which result ${ }^{\text {If }}$ This position implies the view that the disturbance of portfolio equilibrium from any source (not only money stock changes) has powerul repercussions, and thus paradoxically tends to downgrade the importance of changes in the money stock. As far as is known, this position is not supported directly by empirical evidence.

\section{Summary}

In this paper, I lave attempted to sketch the main outlines of monetarist thought and to examine some aspects of the monetarist view of Keynesian analysis. In doing so, I have paid particular attention to the roles of the instruments of stabilization policy under the two views.

My examination of the monetarist-Keynesian debate has indicated that the version of Keynesianism which the monetarists use to establish a contrast for their own point of view is ont of date and inadequate - a

4.Karl Bruner, "The "Monetarist Revolution"." 
"vilgar" version of post-Keynesian thinking, to use Professor Johnson's term. When it is recognized that Keynesianism implies sticky wages and money illusion in the labor market rather than rigid prices, and that portfolio adjustment as the basis for the transmission of monetary impulses is not only consistent with the Keynesian approach but indeed is being buit into Keynesian models, it is seen that there is very little if anything in monetarist theory which is new and different. Rather, the two approaches diverge in ways which basically are methodological and operational. The monetarists are willing to commit themselves to the use of very simple, very small (even one-equation) models for policy analysis; Keynesians typically are not. On this point, the monetarist stance seems to be a matter of faith rather than logic; the common theoretical basis on which both positions rest certainly implies the use of a structural approach. ${ }^{45}$ There certainly are substantial differences in the kinds of operational assumptions that are made about particular dimensions of the theoretical structure, and these have implications of various kinds for policy, The typical Keynesian assumption of money wage inflexblity is consistent with a shorterum analysis; it leacs to the conclusion that both monetary policy and fiscal policy can affect the level of activity. The typical monetarist assumption of wage and price flexibility (i.e., of full employment) is more relevant for the and lysis of secular changes.

This assumption essentially bypasses the whole question of short-run policy effects. For the long run, paradoxically, st suggests that fiscal policy is more important and interesting than monetary policy, for fiscal policy at least changes the rate of interest (unless the rate of interest is exogenously determined). ard therefore the division of output, and presumaby affects growth; whereas monetary policy affects only prices, money wages, and the like. There appear to

\footnotetext{
4kal Brinner has wither, "The moneterise disregards... the allocative detail of credit makets when examinizg pattems of allocation behavior. . . Such detal is simply asm serted. . . to be irelevant for aggregative explanation. Wbil. p. 15 .

4The reservations expressed in fooknote 10 apply to this stateinent a ses.
}

be some analytic confusions in many monetarist discussions. I have tried to show above that it is incorm rect to view the demand-for-money function as a velocity relationship from either point of view. In the monetarist case, this is especially true because the stability of velocity in the face of monetary changes depends on assumptions about the labor market and is unrelated to the characteristics of the demandformoney relationship. It also appears that monetarist fascination with the money stock is unwarranted by monetarist logic, which seems to me to place great emphasis on portfolio disequilibrium as a potent driving force in the economy. It does not follow from this view, as a matter of logic, that observed changes in the money stock have any particular significance as a causative force.

On the positive side, monetarists have contributed to the development of macroeconomic thought by stressing that the links relied upon for years by most Keynesians to connect the real and monetary sectors overlook entirely the important substitution and wealth efects which are the concomitants of portfolio adjustment. They also have called our attention to the distinction, apparently first made by Irving Wisher many years ago, between market and real interest rates, and therefore to the potentially important role of price expectations in dynamic macroeconomics. These phenomena are extraordinarily difficult to capture in empirical models, but work is proceeding along these hines. It is to be hoped that during the next few years, they will be made standard features of Keynesian (that is, structural) theoretical and empirical models, and that dependable evidence will be gathered so that the real questions which divide us - chiefly, in my opinion, the question raised by Brumer and others conceming the need for largescale structural nodels for aggregative analysis - can be answered satisfactorily.

This article and the accompanying one by Robert H. Rasche are avaliable as Reprim No. 74

Appendix begino on following page. 


\section{APPENDIX}

Following are the derivations which underlie equations (4), (8), and (9) in the text. They are based on equations $(1)-(3)$ and $(5)-(7)$, which are reproduced here for convenience:

(I) $y=C(y, r)+I(r)$

(2) $\frac{M_{0}}{\mathrm{~N}}=\mathrm{L}(\mathrm{y}, \mathrm{r})$

(3) $Y=p y$

(5) $y=y(N)$

(6) $\mathrm{N}=\mathrm{ND}(\mathrm{w})$

(7) $w=\frac{W}{\mathrm{p}}$

The following slope assumptions are used throughout: $\mathrm{O}<\mathrm{C}_{\mathrm{y}}<\mathrm{I} ; \mathrm{C}_{\mathrm{r}}<\mathrm{O}$ or, if positive, $\mathrm{C}_{\mathrm{r}}<\mathrm{I}_{\mathrm{r}} ; \mathrm{I}_{1}<\mathrm{O}$; $\mathrm{L}_{\mathrm{y}}>\mathrm{O} ; \mathrm{L}_{\mathrm{f}}<\mathrm{O} ; \mathrm{y}_{\mathrm{V}}>\mathrm{O} ; \mathrm{N}_{\mathrm{w}}^{\mathrm{D}}<\mathrm{O}$.

\section{A. The Elasticity of Velocity}

Equation (4) in the text is an expression for the elasticity of velocity with respect to a monetary shift, and is reproduced for convenience:

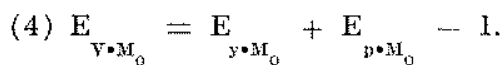

It is derived by differentiating the expression for velocity $\left(V=\frac{Y}{i r}\right)$ with respect to the money stock, and converting the result into elasticity form.

Thus we have:

(A.1) $\frac{\mathrm{dV}}{\mathrm{dM}_{0}}=\frac{1 \mathrm{dY}}{\mathrm{M}_{0}} \frac{\mathrm{dM}}{\mathrm{dM}_{0}}-\frac{\mathrm{Y}}{\mathrm{M}_{0}^{2}}$

From (3), we have

(A.2) $\frac{\mathrm{dY}}{\mathrm{dM_{0 }}}=\mathrm{p} \frac{\mathrm{dy}}{\mathrm{dM_{0 }}}+y \frac{\mathrm{dp}}{\mathrm{d} \mathrm{M}_{0}}$

Substituting (A.2) into (A.1) and multiplying the resulting equation by $\frac{M_{0}}{v}$ yields

(A.3) $\mathrm{E}_{\mathrm{F}_{\mathrm{B} \mathrm{H}_{0}}}=\mathrm{E}_{\mathrm{y} \cdot \mathrm{M}_{0}}+\mathrm{E}_{\mathrm{p} \cdot \mathrm{M}_{0}}-\mathrm{I}$, which is equation (4).

This result is derived only from definitions. Next we investigate the values of $E_{y * M_{0}}$ and $E_{p \cdot m_{0}}$, and therefore of $E_{\mathrm{v}} \mathrm{w}_{0}$, which are implied by monetarist and Keynesian assumptions respectively.

\section{B. The Monetarist Case}

Monetarists assume that wages and prices are flexible so that real output, $y$, may be considered exogenous for the purpose of static analysis, and only equations (1) and (2) are relevant. Differentiating (1), which is the Is curve, yields:

$$
\text { (B.1) } \mathrm{C}_{\mathrm{y}} \frac{\mathrm{dy}}{\mathrm{d} \mathrm{M}_{0}}+\left(\mathrm{C}_{2}+\mathrm{I}_{\mathrm{r}}\right) \frac{\mathrm{dr}}{\mathrm{d} \mathrm{M}_{0}}=\frac{\mathrm{dy}}{\mathrm{d} \mathrm{M}_{0}}
$$

However, if $y$ is exogenous to this system, $\frac{d y}{d M_{0}}=0$ so that we get:

(B.2) $\left(\mathrm{C}_{\mathrm{T}}+\mathrm{I}_{\mathrm{r}}\right) \frac{\mathrm{dr}}{\mathrm{dM}_{0}}=0$, which implies that $\frac{\mathrm{dr}}{\mathrm{d} \mathrm{M}_{0}}=0$.

Differentiating the LM curve (2) yields:

(B.3) $\mathrm{Ly}_{\mathrm{y}} \frac{\mathrm{dy}}{\mathrm{d} \mathrm{M}_{0}}+\mathrm{L}_{\mathrm{r}} \frac{\mathrm{dr}}{\mathrm{d} \mathrm{M}_{0}}=\frac{1}{\mathrm{p}}-\frac{\mathrm{M}_{0}}{\mathrm{p}^{2}} \frac{\mathrm{dp}}{\mathrm{d} \mathrm{M}_{0}}$. Since we have found that, in this case, $\frac{\mathrm{dy}}{\mathrm{dM}_{0}}=\frac{\mathrm{dr}}{\mathrm{dM}_{\mathrm{a}}}=0,(\mathrm{~B} .3)$ reduces to:

$$
\text { (B.A) } \frac{\mathrm{M}_{\mathrm{o}}}{\mathrm{p}} \frac{\mathrm{dp}}{\mathrm{d} \mathrm{M}_{\mathrm{n}}}=\mathrm{E}_{\mathrm{p}+\mathrm{N}_{\mathrm{o}}}=1
$$

Substituting these findings into (A.3), we find that $\mathrm{E}_{\mathrm{y} \cdot \mathrm{M}_{0}}$ - 0 using static analysis under monetarist assumptions.

\section{The Keynesian Case}

Keynesians take money wages to be inflexible while prices are an endogenons variable. This means that real income or output may no longer be considered exogenous; instead, it becomes endogenous, and equations (5)-(7) are added to the IS-LM system as represented by (1) and (2) in order to close the set of equations.

To derive expressions for the elasticities $\mathrm{E}_{\mathrm{y} \cdot \mathrm{M}_{0}}$ and $\mathrm{E}_{\mathrm{p} \cdot \mathrm{u}_{0}}$, we must again differentiate the system totaly with

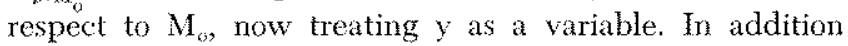
to equations (B.1) and (B.3), this differentiation yields

$$
\text { (C.1) } \frac{\mathrm{dy}}{\mathrm{dM}_{0}}=-\mathrm{y}_{\mathrm{N}} \mathrm{N}_{\mathrm{w}}^{\mathrm{D}} \frac{\bar{W}}{\mathrm{p}^{2}} \frac{\mathrm{dp}}{\mathrm{dM}_{0}}
$$

which is derived by differentiating equations (5)-(7) and substituting where possible.

It will be converient to make some further substitutions. First, since the MPC with respect to income is one rainus the MPS with respect to income, and since the 
$\mathrm{MPC}$ with respect to the interest rate is the negative of the MPS with respect to the interest rate, we make the sabstitutions $\left(1-C_{y}\right)=S_{y}$ and $C_{y}=-S_{y}$, where $\mathrm{S}$ stands for the saving function (the model implies $S=S(y, r)$ ). Second, (C.1) can be used to eliminate the term involving $\frac{4 p}{4 M_{0}}$ in (B.3). Making these substitutions and collecting terms yields the following pair of equations in the two variables $\frac{d y}{d \mathrm{M}_{0}}$ and $\frac{d \mathrm{r}}{\mathrm{dM}_{\mathrm{g}}}$ :

(C.2) $S_{y} \frac{d y}{d M_{0}}-\left(I_{r}-S_{3}\right) \frac{d_{r}}{d_{M} M_{0}}=0$

(C.3) $\left(\mathrm{L}_{y}-\frac{\mathrm{M}_{0}}{\mathrm{~W}_{\mathrm{N}} \mathrm{NWW}_{\mathrm{W}}^{\mathrm{D}}}\right) \frac{\mathrm{dy}}{\mathrm{dM_{0 }}}+\mathrm{L}_{\mathrm{P}} \frac{\mathrm{dr}}{\mathrm{dM}_{o}}=\frac{1}{\mathrm{p}}$

Solving these equations for $\frac{d y}{d M_{0}}$ gives:

(C.4) $\frac{\mathrm{d} y}{\mathrm{~d} \mathrm{M}_{0}}=\frac{\frac{1}{\mathrm{p}}}{\frac{\mathrm{S}_{y} \mathrm{~L}_{\mathrm{F}}}{\mathrm{I}_{\mathrm{r}}-\mathrm{S}_{\mathrm{r}}}+\mathrm{L}_{y}-\frac{\overline{\mathrm{W}}}{\mathrm{M}_{\mathrm{Y}}} \frac{\mathrm{N}_{\mathrm{W}}^{\mathrm{D}}}{}}$

To convert this into elasticity form, two steps are needed:

(a) each of the propensities (or partial derivatives) shown in the denommator may be converted into a partial elasticity by using the relationship between any two variables $x$ and $z$ given by the definition of a partial elasticity; i.e., if $z=f(x)$, then $\eta_{x \cdot x}=f_{x}-\frac{x}{z}$ and thus $r_{x}=\frac{2}{x} \eta_{i \cdot x}$

(b) to find the systemic elasticity $\mathrm{E}_{y \cdot x_{6}}$, both sides of (C.4) must be multiplied by $\frac{\mathrm{H}_{0}}{\mathrm{y}}$. Carrying ont these operations and canceling terms where possible, we get

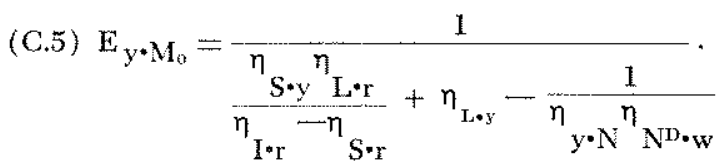

To find an expression for the systemic elasticity $\mathrm{E}_{\mathrm{p}=\mathrm{M}_{\mathrm{N}}}$, equation (C.4) is substituted into (C.1) and a systemic expression for $\frac{d y}{d+F_{0}}$ is derived. When this expression is multiplied by $\frac{\mathrm{N}_{\mathrm{n}}}{\mathrm{n}}$, the partial derivatives are converted to elasticities, and the necessary algebra is carried out, the following expression results:

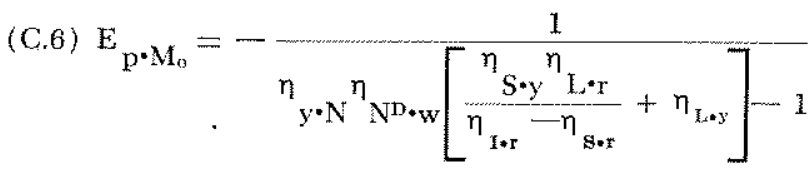

From (C.5) and (C.6), it can be seen that the behavior of velocity now depends on all of the partial elasticities in the system. First, if either $\eta_{y \cdot \mathrm{N}}$ or $\eta_{\mathrm{N}}$ : $\mathrm{w}$ are zero, output will not change in response to a real wage change brought about by a monetary shift, so that $\mathrm{E}_{y} \cdot \mathrm{m}_{0}=0$ and $\mathrm{E}_{\mathrm{p} \cdot \mathrm{N}_{0}}=1$, resulting in stable velocity. Second, if either $\eta_{y * N}$ or $\eta_{Y * W}$ are extremely large, $E_{p * M_{f}}$ approaches zero and the response of velocity to a monetary shift depends on a special case of equation (C.5) in which the last denominator term approaches zero. Whether $\mathrm{E}_{\mathrm{Y} . \mathrm{M}_{0}}$ is positive or negative in this case depends on whether $E_{y_{*} x_{\alpha}}$ is greater or smaller than unity. The condition for $\mathrm{E}_{\mathrm{v}} \cdot \mathrm{M}_{0}$ $<0$ is that

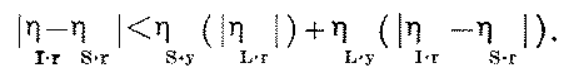

Thus the larger in value are $\eta_{\mathrm{g} * y}, \eta_{L_{*},}$, and $\left|\eta_{\mathrm{E} * \mathrm{r}}\right|$, the more likely it is that $E_{v .0 .}<0$. Finally, for nonzero but finite values of $\eta_{y * \text { N }}$ and $\eta_{x, W_{w}}, E_{y * M_{0}}$ and $E_{p_{*} M_{0}}$ will tend toward zero (and $E_{\text {x.mo }}$ toward -1 ) if $\eta_{\mathrm{s}, \mathrm{y}}$ or ( $\eta_{\mathrm{I}, \mathrm{r}}$ are very large, or if $\left(\eta_{\mathrm{I} \cdot \mathrm{r}}-\eta_{\mathrm{g} \cdot \mathrm{r}}\right)$ is very close to zero in value. A large value for $\eta_{\mathrm{L}^{*+} \mathrm{y}}$ would also give this result. 